\title{
8
}

\section{Between kastom, church and commercialisation: Reconciliations on Bougainville as a form of 'transitional justice'?}

\author{
Volker Boege
}

Peacebuilding on Bougainville is entering a decisive phase. A referendum on the future political status of the island, which is currently an autonomous region within Papua New Guinea (PNG), is scheduled for November 2019. According to the Bougainville Peace Agreement (BPA) of August 2001, the referendum has to include independence as one option. It can be argued that only with the referendum and the peaceful implementation of its result will peacebuilding have reached a satisfactory conclusion.

Reconciliations are seen by Bougainvilleans as an indispensable ingredient of peacebuilding. Countless reconciliations have been carried out already, and there are more to come. Efforts to speed up and complete reconciliations are currently increasing, because unfinished reconciliations are seen as a major obstacle to the conduct of a free and fair referendum. 
While reconciliations are usually presented as the 'traditional' Bougainville approach to conflict resolution and justice, there are now many different types of reconciliations: reconciliations within and between families, clans and villages; between former conflict parties; at the political level in Bougainville; and in national and international politics. Concerns are growing about reconciliations losing their 'traditional' meaning, becoming superficial, tokenistic and commercialised, and thus less effective and legitimate. This could have serious negative impacts on peacebuilding, especially since more formal transitional justice mechanisms are of only minor significance. The BPA granted amnesty and pardon for offences arising out of the violent conflict. In marked contrast to other postconflict political settlements, no provisions for a truth and reconciliation commission (TRC) were put in place. Moreover, the formal court system is underdeveloped in post-conflict Bougainville.

Without a realistic option to take cases to the courts, without a TRC, and with immunity provisions in place, kastom reconciliation became the main avenue for transitional justice. Secular civil society actors, who elsewhere are prominent agents in the transitional justice discourse, are still quite weak in Bougainville. Moreover, they decided to also focus on reconciliations. Finally, the churches, which are by far the most influential civil society institutions on the ground, are deeply involved in reconciliation processes - in fact, kastom reconciliation usually entails Christian principles and practices.

In the following, I will explore the understanding(s) of reconciliation(s) in the local Bougainville context, the current state of reconciliations and their significance as an indigenous means of transitional justice. It will become clear that reconciliations in Bougainville are a long way from the Western transitional justice discourse. There is a tension between Bougainvillestyle reconciliation(s) and the concept of reconciliation as promoted at the international level and pursued in peace interventions that follow the Western liberal peace and transitional justice approach.

\section{Reconciliation(s) Bougainville-style}

The ideal type of Bougainville reconciliation aims at the restoration of social harmony within and between communities and of social relationships between conflict parties (Boege and Garasu 2004; 2011). Reconciliation Bougainville-style is a concept that includes both Christian and kastom 
elements (Garasu 2002; Howley 2002); it is a term deeply rooted in the Christian faith, and at the same time it captures the Bougainville kastom approach to conflict resolution. ${ }^{1}$

Reconciliation is a long-term, complex and complicated multifaceted process in which the wrongs of the past are acknowledged, responsibility is accepted and shared, and the basis for a common future is created. Reconciliation breaks the cycle of pay-back (retribution), reconstructing relations and trust.

It basically comprises the following stages:

first of all, an agreement between the two sides to reconcile, followed by a meeting with an exchange of gifts to show that peace has been restored and a first public reconciliation has taken place. Later, there will be further reconciliations and, finally much later, the offenders will very likely meet face to face with the victims and/or their relatives, admit their guilt, express sorrow and will be forgiven. (Howley 2002, 109) ${ }^{2}$

Often there is no clear-cut boundary between victims and perpetrators. The victims of today might have been the perpetrators in the past, and vice versa. In a war like the one fought in Bougainville, the phenomenon of victims-turned-perpetrators and perpetrators-turned-victims is quite common. And these victim-perpetrators have to live together again and to build a shared future in closely knit communities.

The conflict parties striving for reconciliation usually invite a neutral third party to steer the process, mostly respected community leaders who are highly esteemed for their knowledge of kastom, the history of communities and relationships of the parties in conflict, of kinship ties and of social circumstances prevailing in the conflict setting. As Bougainville has an oral culture, their knowledge of stories and their skills in storytelling are

1 Kastom, a Pidgin derivative of the English 'custom', is referred to by both politicians and grassroots people in Melanesia today in order to stress their cultural heritage and the difference between their own ways and foreign ways of governance, often depicting kastom as rooted in ancient pre-colonial traditions, a set of rules developed by the ancestors (Keesing 1993, 589). Kastom governance is thus presented as the other of, or even alternative to, introduced state-based institutions and forms of governance. At the same time, kastom is different from the customs of the pre-contact past. It has developed since the times of first contact and colonisation in the course of interaction and exchange of pre-contact custom and various external influences - Christian missions, colonial administrations, institutions of the nation state and the market economy. Hence kastom is not anachronistic, fixed and static, it continually changes in the course of dealing with new challenges.

2 For an ideal typical traditional reconciliation process, see Tanis (2002). 
important for the process. Their rich experience, their skills in setting (and interpreting) signs of reconciliation enable them to reach a resolution that is acceptable to all sides.

In the process, a common understanding of the causes and the history of the conflict has to be developed. Conflict parties have to negotiate a consensus regarding the interpretation of the past. Only once such a consensus has been achieved can reconciliation take its course. Perpetrators are helped to see their roles in the conflict more clearly, retrace their steps, acknowledge that they have disrupted social networks and even caused violence. This is the foundation for taking responsibility for their wrongdoings and for admitting guilt. Perpetrators then have to apologise to the ones they wronged and ask for forgiveness. Victims must develop a willingness to accept the apologies and forgive. Heartfelt repentance and confession on the part of the offenders and heartfelt forgiveness on the part of the victims are the building blocks of reconciliation. Reconciliation is not 'forgive and forget', but to remember without feelings of hatred and desire for revenge.

This kind of reconciliation is not a one-off event or a quick fix. It needs time. Slowness, breaks and 'time outs' are deliberately built into reconciliation processes to give parties time to calm down, assess the state of the process so far, reformulate their position and to prepare themselves spiritually and emotionally for a resolution.

Once solutions are found, they are ratified in highly ritual forms. Ceremonies mark the culminating points of the reconciliation process. Usually there is not one reconciliation ceremony, but a series of ceremonies, according to the progress of reconciliation. The ceremonies vary from area to area, ${ }^{3}$ but generally they encompass rituals such as breaking spears and arrows, drinking and eating together from the same dish, singing and dancing together or chewing betelnut together. These symbolic activities are expressions of commitment and trust and are more powerful than mere spoken or written words. Finally, gifts are exchanged (pigs, shell money, food, cash or a combination of all these items).

3 In some places, for instance, people bury large stones. "The significance of the stone is that it is heavy and it does not move and it gives a sign of strong and unchanging reconciliation between the people' (Howley 2002, 111). In other places the parties 'would plant tangget plants on stone. This symbolised their promise to forget the past and remain as silent as stone. Anyone who violated this agreement would be cursed by the stone and any talebearer would be punished by its strength' (Tanis 2002, 59). 
The whole community participates. Church services and prayers are usually an integral part of these activities, as 'Christian principles of reconciliation have conveniently found their place in the culture and have, indeed, added a great deal to the process, through the incorporation of prayers and public acknowledgements by priests and church ministers' (Tanis 2002, 60). ${ }^{4}$ Church leaders were and are particularly active in initiating and stabilising reconciliation processes. There are reconciliations that are carried out in the church context only. They are cheaper (no compensation has to be paid), but often also lack legitimacy because the kastom dimension is missing. They tend to be seen as a kind of 'second class' reconciliation, although for strong Christian believers they can be the 'real' reconciliations. The involvement of the churches is the most significant and visible expression of 'civil society' participation in reconciliation processes, although the people who participate in these reconciliations hardly think of the churches as civil society actors in the Western liberal sense of the term.

Reconciliation ceremonies are loaded with spiritual meaning. Ceremony is an important vehicle for cleansing and purification. Mental healing is an important aspect of reconciliation. Reconciliation is not only an issue of reason and the intellect. It is a deeply emotional and spiritual experience. Reconciliation is about deeply felt remorse, shame and the desire for forgiveness. It is about deeply felt grief, anger and sorrow and the desire to forgive. It is about mending hearts. ${ }^{5}$ It is about repairing broken relationships and restoring harmony so that people can live in peace not only with each other, but also with God and the spirits of the dead. God is present in reconciliation, and so are the spirits of the dead. ${ }^{6}$ Social relations are guarded by the spirit world. Whenever social relations break down, the spirit world is affected. The worlds of the living and the dead are closely interconnected. Conflicts also play out in the spirit world. This is why cleansing rituals that appease the spirits are linked to reconciliation. If such cleansing rituals are not performed, the spirits of the fallen will not rest but come back and haunt the living. If the spirits of the dead cannot be appeased, all kinds of misfortune will befall

4 This is very similar to the relationship between kastom and Christianity in the Solomon Islands, see Jeffery $(2013,213)$.

5 See the title of Pat Howley's highly informative and moving book: Breaking Spears and Mending Hearts (Howley 2002).

6 Most Bougainvilleans are devout Christians, but this does not replace belief in the spirit world. Rather, this goes together; there is mixing and blending. 
the communities - illness, accidents, madness, death. So in the course of a reconciliation process the spirits will be called on to remove any illness that has befallen the community because of the conflict and bring back healing to the sick and the community at large.

Proper burials of the dead are highly important. In fact, one major problem for reconciliation after the war was, and still is today, that many people who were killed have not been buried in a culturally appropriate manner. Relatives do not know where the remains of their kin are, or there are graves with bones that have not been identified. In order to find peace and to reconcile, the dead have to be given a proper burial (UNDP 2014, 12, 32). The unburied dead have an influence on the lives of the living, both the perpetrators and the relatives of the victims. Therefore, finding and bringing home the bodies, burying them properly and grieving at their graves is an indispensable dimension of reconciliation. This is why the topic of 'missing persons' looms large in the current stage of peacebuilding on Bougainville. ${ }^{7}$

With reconciliation at the heart of peacebuilding, justice is restorative rather than punitive (although punitive/retributive elements can be part of kastom conflict settlements). On Bougainville today there is much talk about restorative justice. This modern term mirrors the approaches to justice that were and are an integral part of Bougainville customary conflict resolution (Braithwaite, Charlesworth, Reddy and Dunn 2010, 122-124). As a Bougainville chief states: 'Restorative justice is not a new method in our societies. It is what our ancestors used for thousands of years to resolve minor and major disputes, up until colonial times' (Tombot 2003: 259). It is grounded in a fundamentally relational understanding of people and society - an understanding that necessitates and enables justice to be pursued as a way of restoring relationships that were severed,

\footnotetext{
7 Similar beliefs can be found in other post-conflict societies in the Global South. For East Timor, for example, Robins reports that a central need of victims 'was the performance of rituals that would permit the spirits of the dead to rest in peace, and this was emphasized in Timor where the consequences of not performing rituals for the dead were believed to be the potential sickness and death of family members' (Robins 2013, 53). 'For Timorese families a malign spirit is the most negative potential impact of a missing relative; addressing the issue of those who died in the conflict means not only addressing the needs of their families but also the demands of the spirits ... the peace of the nation is dependent upon this, with recent violence perceived as arising from the many spirits of the conflict dead still not at rest' (Robins 2013, 54; see also Grenfell, Chapter 2, this volume).
} 
disrupted or destroyed by violence and wrongdoing. ${ }^{8}$ Priority is given not to the punishment of individual offenders, but to the restoration of social harmony within and between communities and the restoration of relationships between the communities of offenders and victims. In Bougainville, reconciliation and restorative justice are 'twin frameworks for peacebuilding' (Llewellyn and Philpott 2014, 14).

For restorative justice and reconciliation, the exchange of gifts plays an important role. Gifts to compensate for damage done and wrongs committed serve to cement reconciliation. Reconciliations thus do not only aim at spiritual and emotional healing, but they also have a material side. Reparations are signs for and part of restoring relationships. Traditionally, gifts were items held precious by the communities such as shell money, pigs, mats and food. Nowadays cash and modern goods are also exchanged. Gifts are exchanged as a symbol of the restoration of relationships. The exchange is an outward sign of reconciliation. Its purpose is to 'wash away the tears'. A Bougainville elder explains:

When we make peace, it is not the food and it is not the pigs and it is not the speeches. It is the people saying 'I forgive you. You forgive me. Let us get on with our lives'. All the rest - the pigs, and the food and the speeches - are just the outwards signs of our peace making. The shell-money is something that people see and they can put their mind on as the sign of our making peace. (Peter Mekea, quoted from Howley 2002, 103)

Pat Howley makes a clear distinction between such an exchange of gifts and compensation, and he explains the difference as follows:

Gifts - yes, restitution for damages such as burned houses - yes, but no compensation. A gift is to wash away the tears; it in no way is a payment for the loss incurred. Compensation is for gain and is equivalent to setting a value on the life of a loved one. With a gift, one asks for forgiveness; with compensation, there is no forgiveness and the person is attempting something which is impossible, that is putting a value on something that cannot be bought or paid for. (Howley 2002, 126)

8 On restorative justice and reconciliation as relational conceptions of justice as opposed to a liberal individualist notion with its focus on individual offenders and their punishment, see Llewellyn and Philpott (2014). 
In reality, however, this distinction, with the giving of gifts as an integral part of kastom reconciliation, and compensation (meaning in particular the payment of cash) as a deviation from kastom, is becoming more and more blurred. People complain that the 'true' customary meaning of the exchange of material goods in the context of reconciliation processes is being lost. There are indeed people who try to instrumentalise reconciliation, including those who use reconciliation and accompanying compensation to make money (see below).

So let us have a closer look at the realities of reconciliation(s) on Bougainville today.

\section{Reconciliations today - between kastom and commercialisation}

Part of the post-conflict political settlement on Bougainville was the constitutional guarantee of immunity from prosecution in respect of offences arising from crisis-related activities. The Lincoln Agreement of January 1998, which terminated violent conflict, declaring a 'permanent and irrevocable ceasefire', as well as the BPA-granted amnesty and pardon 'for all persons involved in crisis related activities or convicted of offences arising out of crisis related activities' (BPA, clause 33). ${ }^{9}$ Immunity regulations were incorporated into the PNG and Bougainville constitutions. They covered a broad range of issues and in general applied to the time period between 1 October 1988 and 30 August 2001 (signing of the BPA). ${ }^{10}$

The amnesty and pardon regulations were complemented by the decision to deal with human rights abuses and other wrongs committed during the war through kastom reconciliation. The Bougainville Constitutional Commission (BCC) in its final 2004 report recommended that 'as far as possible ... Bougainville kastom' should be used 'when dealing with human rights abuses and pursuing reconciliation' (BCC 2004, 199); and

9 The BPA states that 'the arrangements for pardon and amnesty are intended to reduce tensions and divisions that could continue to flow from the conflict' (BPA, clause 341(d)). See also clause 10 (Amnesty and Pardon) of the 'Lincoln Agreement on Peace, Security and Development on Bougainville', 23 January 1998.

10 See Constitution of the Autonomous Region of Bougainville, Schedule 6.1 and 6.2. Declaration in respect of immunity (pp. 159-160). There are exceptions for which other dates were set, in particular with regard to the possession, ownership and control of firearms. 
in cases where the courts would become involved, they would have to 'take any customary settlements of matters before them into account' (ibid.). ${ }^{11}$ Clause 185 in the Bougainville Constitution allows for the establishment of 'a special human rights enforcement body' with powers to 'encourage reconciliation among parties involved in abuses or infringement of human rights (including all parties in the Bougainville conflict)', and clause 186 stipulates that 'customary methods of dealing with such abuses [of human rights] should be utilized wherever possible'. Such a 'special human rights enforcement body' has not been set up. No truce and reconciliation commission was established. Whether to have one or not was discussed, but no consensus could be reached (Wallis 2014, 294), and the debate about pros and cons of a TRC is ongoing even today. ${ }^{12}$

With the immunity provisions in place, without a realistic option to take cases to the courts and without a TRC, kastom reconciliation in fact became the main avenue for transitional justice. And in general it has worked well.

There is no doubt about the importance of kastom reconciliation for peacebuilding on Bougainville (Braithwaite, Charlesworth, Reddy and Dunn 2010,67-76). As the war was not only waged between the government of PNG and its Bougainvillean allies on the one hand and the secessionist Bougainville Revolutionary Army (BRA) on the other, but a complex mixture of this 'big' war and a host of 'mini wars' that were fought under the umbrella of the 'big' war in various local contexts, it was not sufficient to merely end the war of secession by political negotiations, it was also necessary to terminate the 'mini wars' and build peace at the local level. The parties fighting each other were not anonymous mass armies but mostly people who knew each other they were 'intimate enemies' (Theidon 2006). Building peace between them was done by drawing on kastom ways of conflict resolution and reconciliation. This happened in many places all over Bougainville over the last two decades, and it continues today. These 'local reconciliation efforts have done more to consolidate popular commitment to peace than any other aspect of the process' (Regan 2001, 15). They were the means to restore social networks and relations that had broken down during the war, and to restore social trust and a sense of moral order. Secular

11 See Constitution of the Autonomous Region of Bougainville, clauses 185 and 186.

12 In neighbouring Solomon Islands a different path was taken, with mixed results. See Jeffery 2013; Cronin, Chapter 10, this volume. 
civil society organisations were involved to a certain extent. Oftentimes supported by international partners like Care Australia, Save the Children or the International Committee of the Red Cross/Red Crescent, local NGOs (for example, the Nazareth Centre for Rehabilitation, Nasioi Peacebuilding Association, Bougainville Indigenous Dialogue or the Bougainville Healthy Communities Program) carried out specific peace projects that initiated or contributed to reconciliations. Even more important, however, were the churches, given their local embeddedness in each and every place in Bougainville.

The processes at the grassroots level were of decisive importance for the stabilisation of the overall peace and the success of peacebuilding at the 'higher' political levels. While in conventional Western academic and political thinking the top-down story is the master narrative and the bottom-up reconciliations are subsidiary', in the Bougainville case 'in important ways the bottom-up micro narratives subsume and infuse the top-down peace' (Braithwaite 2011, 140). While secular civil society organisations have only played minor roles, the churches, embedded as they are in the local context, have managed to substantially influence and shape these 'micro narratives'.

There are problems, however. Some reconciliation processes have been dragging on for a long time, and others have not yet started. Particularly in light of the November 2019 referendum there is a growing sense of urgency with regard to outstanding or unfinished reconciliations, and efforts to speed up reconciliations are intensifying. In recent times, so-called 'mass reconciliations' have gained prominence. In these 'mass reconciliations' a number of diverse cases in one region are lumped together and dealt with in one process. The last phase before the referendum, from mid-2018 onwards, saw a marked increase in the numbers of mass reconciliations dealing with crisis-related issues. They often were organised by District Peace and Security Committees (formal governance institutions). They have taken place in various regions of Bougainville, even in areas where current non-crisis-related divisions run deep (e.g. in the Panguna mine area). Mass reconciliations draw wide public attention, and they are propagated by the political elite as the means to finally wrap up the reconciliation business. It is not clear how effective and legitimate these mass reconciliations will be in the longer term. They clearly represent a deviation from what so far has been seen as kastom reconciliation. Such mass reconciliations serve a political purpose, which is important but can leave wounds open at the interpersonal level. In general, people 
approve of mass reconciliations because they see the need to speed up reconciliation processes in view of the upcoming referendum, but they also insist on the significance of more intimate clan-, family- and groupbased reconciliations. Often these 'small' reconciliations are perceived as stepping stones towards mass reconciliations. One view is that the small 'clan' or 'ward' reconciliations have to come first, and the bigger 'community' or 'mass' reconciliations later. Others, however, hold the view that initial more symbolic mass reconciliations can serve as the starting point for more meaningful and effective 'small' reconciliations.

Then there is the issue of money. Reconciliations are costly, and they can be used as a money-making device. Bringing people together for reconciliation ceremonies and feeding them, and providing the gifts/ compensation items, often costs a lot of money. This is why parties who want to reconcile increasingly ask for outside assistance, mainly in the form of cash. Such outside assistance started in the times of the Peace Monitoring Group (PMG) and the United Nations Observer Mission on Bougainville (UNOMB) immediately after the war. Over time it became more and more normal that outsiders would provide the resources that make reconciliations possible, and for conflict parties to demand such outside support (UNDP 2014, 12). Today, for example, the Australianfunded Bougainville Peacebuilding Program pays for reconciliations. Sometimes this even goes as far as parties demanding the money they have to pay as compensation from outside sources. In fact, compensation is increasingly in the form of cash - in addition to or instead of traditional items such as pigs or shell money. Reconciliations today can be a means to make money. Moreover, many reconciliations today are not crisis-related any more, but deal with post-crisis or current issues, and sometimes one gets the impression that conflicts are incited in order to make money out of the ensuing reconciliations.

Bougainvilleans have a tendency to blame outsiders for the commercialisation/monetisation/commodification of reconciliations these outsiders brought the money in and thus distorted the true meaning of Bougainville customary reconciliation, undermining its legitimacy. Over and over again you can hear the complaint that it is all about money'. But at the same time, many Bougainvilleans also complain about the cost of reconciliations and say that they therefore need the money from outside sources. 
Despite this trend, many of today's reconciliations are not commercialised, with conflict parties deliberately abstaining from compensation in the form of money (or with money only as a minor element in the mix of gifts exchanged), and the parties themselves providing the food, covering the costs of transport and so on. People are very proud of these - as they see them - 'true' reconciliations, contrasting them with what they call phoney reconciliations. Phoney reconciliation is superficial, hollow tokenism or a way to make money. A report about such a phoney reconciliation says that it 'meant nothing because the organisers used government money and the preparation and the discussion essential to any genuine reconciliation did not take place' (Howley 2002, 17). This kind of phoney reconciliation is in itself a cause of conflict, because people 'are angry because the value of the traditional form has been debased by people in high places' (Howley 2002, 117) who make 'reconciliation' 'a sham' (ibid., 118).

This criticism often is applied to reconciliation efforts in the political realm. When it comes to reconciliation in the context of politics, things become difficult indeed. Reconciliation at the interpersonal level is a painful and complicated emotional and spiritual process, and these dimensions are usually excluded from the political sphere. Nonetheless, people expect that their leaders who deal with the high-level political processes also pay due attention to the necessities of reconciliation, but then often criticise as hollow tokenism the inclusion of gestures of reconciliation into political negotiations and agreements. Nevertheless, paying tribute to customary and Christian symbols of reconciliation in the high-level political context has contributed to peacebuilding. It is of importance for the people to see their leaders adhere to kastom reconciliation, even if political reconciliations are of another quality than the interpersonal customary community reconciliations described above (Tanis 2002). ${ }^{13}$

There is a lot of talk about the need to reconcile with 'Papua New Guinea', or with 'Australia', or with the 'Papua New Guinea Defence Force' (PNGDF). On the other hand, there is a lot of uncertainty about what this could look like. National or international reconciliation is obviously different from reconciliation in the local interpersonal context. Attempts for reconciliations with the PNG Government and the

13 On the relation between 'bottom-up interpersonal reconciliation' and 'top-down political reconciliation on the grand scale' see Bloomfield (2006, 27-28). 
PNGDF that so far have been made are generally seen as unsatisfactory, and political leaders are blamed for that. Almost the same difficulty arises with regard to reconciliations between the political leaders of various Bougainville factions - for example, between the Autonomous Bougainville Government (ABG) and the Meekamui movement, or between the various factions of Meekamui. ${ }^{14}$ The big question is how to upscale or transfer an approach that works in the local community context to other contexts, without that approach being instrumentalised and thus losing legitimacy and effectiveness.

This is a fundamental question, which points to the limits of customary reconciliation. From what has been said so far, it should have become clear that customary reconciliation hinges on the existence of a community of relationships and values that are rooted in a common view of the world and a shared acknowledgement of customary institutions. It works within and between relatively small communities in the local context. Conflicts among the members of the 'we-group' of the community can be addressed and solved this way. Conflicts between neighbouring local communities pose relatively small problems, because some overarching customary principles can usually be developed and applied that allow for the creation of common ground. In other words: kastom reconciliation works for 'intimate enemies' (Theidon 2006), people who are bound by some kind of relationships, a shared worldview and shared norms. Dealing with outsiders is much more difficult. Conflicts between 'us' and 'them', who do not share our culture, are much more difficult to tackle. If 'they' do not understand, do not respect, or are unwilling to be included in 'our' ways of conflict resolution, reconciliation becomes very difficult or even impossible (Boege 2006).

14 The Meekamui movement emerged from the BRA. It comprises those ex-BRAs who have not joined the peace process officially, but also do not disrupt it. Meekamui is still in control of the area around the Panguna mine in central Bougainville and pockets of territory in South Bougainville. The Meekamuis have their own structures of governance, but also cooperate with the ABG. The 'border' between the Meekamui-controlled areas and the rest of Bougainville is rather porous, and there is considerable exchange. Over the years, the Meekamui movement has split into several factions. At present, complicated processes of rapprochement between the ABG and Meekamui, between the different Meekamui factions, and between the Meekamuis and their former comrades from the BRA, are underway, which might lead to some kind of 'reunification' in the future. In light of the upcoming referendum on independence, there is general agreement that 'unity' of all Bougainville political factions is urgently needed, and efforts have intensified to achieve that unity. In 2016 and 2017 several important reconciliations between these political factions have taken place. 
This problem became obvious in the attempts to reconcile with Rio Tinto/Bougainville Copper Limited (BCL), the company that operated the Panguna mine and that by many Bougainvilleans is seen as the main culprit in the Bougainville saga. ${ }^{15}$ There is general acknowledgement that there has to be reconciliation with Rio Tinto/BCL and, over the last years, BCL had indicated that it was willing to come in for reconciliation. A lot of thought and effort from various sides was put into making 'bel kol' possible (McKenna 2015). Bel kol (cooling of the heart) is the very first symbolic step in a longer reconciliation process, a gesture of willingness to start reconciliation. Various dates for a bel kol ceremony were announced, but the ceremony had to be postponed again and again. Stakeholders could not agree on the content, form and meaning of bel kol, and some stakeholders remained opposed to it. The consensus necessary for reconciliation could not be reached. There were some who said that bel kol, as planned, would not be genuine reconciliation, but only about money. And there were others who obviously were interested in just that: money, who wanted to make more money out of bel kol. Now that the BCL majority shareholder Rio Tinto has walked away from $\mathrm{BCL}$ and the Panguna mine, most probably there will be no bel kol in the forseeable future.

Another fundamental question concerns the relationship between kastom reconciliation and human rights, and women's rights in particular. ${ }^{16}$ Whether serious human rights violations and crimes such as torture or pack rape that were committed during the war can appropriately be dealt with in the frame of kastom reconciliation is questionable. There was considerable sexual violence against women during the Bougainville war, which is difficult to discuss in public. ${ }^{17}$ Here the question arises as to whether 'traditional' kastom reconciliation is adequate to deal with 'modern' forms of violence that had not been part of traditional societal life and conflict. In other words, kastom reconciliation is not a panacea for all ills. Joanne Wallis rightly makes the point that 'the decision to prioritise local customary reconciliation over prosecution in formal justice institutions for crimes committed during the crisis, and the resulting

15 Bougainville Copper Limited (BCL) was majority owned by Rio Tinto (previously Conzinc Riotinto of Australia (CRA)). In 2016, Rio Tinto withdrew from BCL and transferred its shares in the company to the ABG and the PNG Government.

16 See Wallis, Chapter 7, this volume; George 2016.

17 This is similar to Solomon Islands or East Timor. For those cases, see Guthrey (2016) and Vella (2014a, 2014b). On the 'perceived incompatibility between cultural norms and publicly airing sensitive stories' (Guthrey 2015, 5), see Guthrey (2015, 161-162). 
developing culture of impunity, highlights the challenge of achieving a balance between liberal and local customary practices' (Wallis 2014, 296; see also Wallis, Jeffery and Kent 2016, 174).

Finally, there is the question of power relations. Power is not absent from reconciliation. Who is in a position to determine the need for reconciliation in a specific case? Whose interests are served, and whose not? How do power imbalances play out in reconciliation processes?

Imbalances with regard to age, kinship networks or resourcefulness play a role, but the most prominent imbalance is gender related; with regard to 'asymmetries in power structures, gender relations and gender-specific experiences of violence need to be considered' (Fischer 2011, 423). Although it would be misleading to think of women in Bougainville as generally powerless or less powerful than men, ${ }^{18}$ in certain contexts gendered power relations are significant, and this can affect the position of women in reconciliations. Furthermore, young people generally have a lesser status in communities than older people. The very old, old widows in particular can also be powerless (if they lack family support), and there are clans or extended families that are more powerful than others. These power asymmetries can all affect reconciliations. ${ }^{19}$

\section{Conclusions}

Reconciliations in Bougainville have not much to do with the Western reconciliation and transitional justice discourse. That discourse does not pay much attention to historical, social and cultural contexts. In fact, as 'a highly normative formula with universalist claims, the reconciliation discourse tends to make context a blind spot' (Eastmond 2010, 5). Or, as Erin Baines put it: 'International and national policy makers have imposed a uniform approach on justice after conflict, ignoring the complex local dynamics that are most relevant to people's lives' (Baines 2010, 415).

18 Most communities in Bougainville are matrilineal, with a relatively strong position of women in the customary social context. Bougainville women were highly influential actors in peacebuilding (Havini and Sirivi 2004; King 2009).

19 For a critique of 'ethnojustice', including customary reconciliation, see Branch (2014), who argues that this type of justice consolidates 'a patriarchal, gerontocratic order' (p. 616) and 'empowers older men at the expense of youth and women' (p. 619). 
Reconciliations in Bougainville are indeed highly context-specific, and the term has to be understood in this specific context. Bougainville reconciliations serve communities for which the maintenance of social relationships is essential to their members' material and spiritual wellbeing and security. They are geared towards the restoration of relationships between 'intimate enemies' after violent conflict, including the restoration of relationships with the spirit world and God. They do not necessarily lead from point $\mathrm{A}$ - violence, conflict - to point $\mathrm{B}$ - conflict resolution, harmony - in a linear way. They are complex and open-ended; 'final settlements' are not 'final' at all, but are open to renegotiation at some time in the future. The past is not past: it can resurface (or be made to resurface) at any time; 'resolutions' therefore are not really 'resolutions'. Accordingly, reconciliation 'describes a process rather than an end state or outcome' (Fischer 2011, 415). This does not fit well with the conventional mainstream understanding of transitional justice in the Western-dominated international discourse.

Reconciliations are embedded in the everyday life of communities as merely one aspect. People want to get on with their 'normal lives', and reconciliations matter only inasmuch as they (hold the promise to) make this possible. This pragmatic approach to reconciliation pays attention to restorative justice and material reparation, at the same time though it is not in contrast to the emotional and spiritual importance of reconciliation; rather, the material and the spiritual elements go hand in hand, given that everyday life is imbued with spirituality and emotions. Reconciliations that are motivated by pragmatic considerations do not pay much attention to legal concerns. They are definitely not the functional equivalent of legal procedures. ${ }^{20}$ Legal, normative and institutional questions are of little relevance to these reconciliations, which are embedded in specific worldviews and cosmologies, from which they draw their meaning and moral might. Furthermore, Bougainville reconciliations connect reason and emotion. While in Western concepts, peacebuilding is (or is presented as being) very much an issue of reason, rational procedures and rational politics, for Bougainville reconciliations, feelings and spirituality are crucial. Rational elements play a role, but peace cannot be built, and justice cannot be restored, without addressing people's emotions and spirituality. This is why the churches have

20 It is a common misunderstanding that 'customary law', 'traditional courts' and 'customary conflict resolution' are functional equivalents of, and can operate like, statutory law, state courts and alternative dispute resolution, filling the gaps if the latter are absent. 
a prominent place in Bougainville reconciliations, in contrast to secular civil society organisations that are bound to Western understandings of transitional justice.

Finally, one significant advantage of reconciliations of the Bougainville type is that people can implement them themselves: they have agency, they are in control, they have voice. Reconciliations are sociocultural mechanisms at people's immediate disposal, they are familiar with the process and they know what outcomes can be expected. This marks an important difference to TRCs, trials and other mechanisms of transitional justice; these are not at the disposal of and under the control of ordinary community members, they lack clarity of process and outcomes for the community, and in them victims and perpetrators are largely objects of external mechanisms (Guthrey 2015, 2016). This is not to say that TRCs and so forth cannot be valuable and necessary. What I tried to say in this chapter is that context-specific, locally grounded reconciliation can make a decisive contribution to peacebuilding. This, at least, is the case in Bougainville, and perhaps this type of reconciliation is actually transitional justice.

\section{Bibliography}

Baines, Erin. 2010. 'Spirits and Social Reconstruction after Mass Violence: Rethinking Transitional Justice'. African Affairs 109 (436): 409-430. doi.org/ 10.1093/afraf/adq023.

BCC (Bougainville Constitutional Commission). 2004. Report of the Bougainville Constitutional Commission. Report on the Third and Final Draft of the Bougainville Constitution. Arawa and Buka: Bougainville Constitutional Commission.

Bloomfield, David. 2006. On Good Terms: Clarifying Reconciliation. Berghof Report no. 14. Berlin: Berghof Research Center for Constructive Conflict Management.

Boege, Volker. 2006. Traditional Approaches to Conflict Transformation - Potentials and Limits. Berghof Handbook for Conflict Transformation. Berlin: Berghof Research Center for Constructive Conflict Management. 
Boege, Volker and Lorraine Garasu. 2004. 'Papua New Guinea: A Success Story of Postconflict Peacebuilding in Bougainville'. In Searching for Peace in Asia Pacific: An Overview of Conflict Prevention and Peacebuilding Activities, edited by Annelies Heijmans, Nicola Simmonds and Hans van de Veen, 564-580. Boulder and London: Lynne Rienner.

Boege, Volker and Lorraine Garasu. 2011. 'Bougainville: A Source of Inspiration for Conflict Resolution'. In Mediating across Difference. Oceanic and Asian Approaches to Conflict Resolution, edited by Morgan Brigg and Roland Bleiker, 163-182. Honolulu: University of Hawai'i Press. doi.org/10.21313/ hawaii/9780824834593.003.0009.

Braithwaite, John. 2011. 'Partial Truth and Reconciliation in the Long Durée'. Contemporary Social Science 6 (1): 129-146. doi.org/10.1080/17450144.2010. 534498.

Braithwaite, John, Hilary Charlesworth, Peter Reddy and Leah Dunn. 2010. Reconciliation and Architectures of Commitment: Sequencing Peace in Bougainville. Canberra: ANU E Press. doi.org/10.22459/RAC.09.2010.

Branch, Adam. 2014. 'The Violence of Peace: Ethnojustice in Northern Uganda'. Development and Change 45 (3): 608-630. doi.org/10.1111/dech.12094.

Constitution of the Autonomous Region of Bougainville. 2005. Buka: Autonomous Bougainville Government.

Eastmond, Marita. 2010. 'Introduction: Reconciliation, Reconstruction, and Everyday Life in War-Torn Societies'. Focaal-Journal of Global and Historical Anthropology 57: 3-16. doi.org/10.3167/fcl.2010.570101.

Fischer, Martina. 2011. 'Transitional Justice and Reconciliation: Theory and Practice'. In Advancing Conflict Transformation. The Berghof Handbook II, edited by Beatrix Austin, Martina Fischer and Hans-Joachim Giessmann, 405-430. Opladen: Barbara Budrich Verlag.

Garasu, Lorraine. 2002. 'Women Promoting Peace and Reconciliation'. In Weaving Consensus - The Papua New Guinea-Bougainville Peace Process, edited by Andy Carl and Lorraine Garasu, 28-31. Conciliation Resources Accord Issue 12/2002. London: Conciliation Resources.

George, Nicole. 2016. 'Light, Heat and Shadows: Women's Reflections on Peacebuilding in Post-Conflict Bougainville'. Peacebuilding 4 (2): 166-179. doi.org/10.1080/21647259.2016.1192241.

Guthrey, Holly L. 2015. Victim Healing and Truth Commissions: Transforming Pain through Voice in Solomon Islands and Timor-Leste. New York and London: Springer. doi.org/10.1007/978-3-319-12487-2. 
Guthrey, Holly L. 2016. 'Local Norms and Truth Telling: Examining Experienced Incompatibilities within Truth Commissions of Solomon Islands and Timor Leste'. The Contemporary Pacific 28 (1): 1-29. doi.org/10.1353/cp.2016.0009.

Havini, Marilyn T. and Josephine Tankunani Sirivi, eds. 2004. ... As Mothers of the Land: The Birth of the Bougainville Women for Peace and Freedom. Canberra: Pandanus Books.

Howley, Pat. 2002. Breaking Spears and Mending Hearts: Peacemakers and Restorative Justice in Bougainville. London - Annandale: Zed Books The Federation Press.

Jeffery, Renée. 2013. 'Reconciliation and the Rule of Law in the Solomon Islands'. In Transitional Justice in the Asia Pacific, edited by Renée Jeffery and Hun Joon Kim, 195-227. Cambridge: Cambridge University Press. doi.org/ 10.1017/CBO9781139628914.007.

Keesing, Roger M. 1993. 'Kastom Re-examined', Anthropological Forum 6 (4): 587-596. doi.org/10.1080/00664677.1993.9967434.

King, Barbara. 2009. 'Women and Peacebuilding: A Feminist Study of Contemporary Bougainville'. PhD thesis, University of Queensland.

Llewellyn, Jennifer J. and Daniel Philpott. 2014. 'Restorative Justice and Reconciliation: Twin Frameworks for Peacebuilding'. In Restorative Justice, Reconciliation, and Peacebuilding, edited by Jennifer J. Llewellyn and Daniel Philpott, 14-34. Oxford: Oxford University Press. doi.org/10.1093/ acprof:oso/9780199364862.003.0002.

McKenna, Kylie. 2015. 'Mining and Reconciliation: Negotiating the Future of the Panguna Mine in Bougainville'. SSGM In Brief 2015/35. Canberra: ANU.

Regan, Anthony. 2001. 'Why a Neutral Peace Monitoring Force?' The Bougainville Conflict and the Peace Process'. In Without a Gun: Australians' Experiences Monitoring Peace in Bougainville, 1997-2001, edited by Monica Wehner and Donald Denoon, 1-18. Canberra: Pandanus Books.

Robins, Simon. 2013. 'An Empirical Approach to Post-Conflict Legitimacy: Victims' Needs and the Everyday'. Journal of Intervention and Statebuilding 7 (1): 45-64. doi.org/10.1080/17502977.2012.655618.

Tanis, James. 2002. 'Reconciliation: My Side of the Island'. In Weaving Consensus: The Papua New Guinea-Bougainville Peace Process, edited by Andy Carl and Lorraine Garasu, 58-61. Conciliation Resources Accord Issue 12/2002. London: Conciliation Resources. 
Theidon, Kimberly. 2006. 'Justice in Transition: The Micro-Politics of Reconciliation in Postwar Peru'. Journal of Conflict Resolution 50 (3): 433-457. doi.org/10.1177/0022002706286954.

Tombot, John. 2003. 'A Marriage of Custom and Introduced Skills: Restorative Justice Bougainville Style'. In A Kind of Mending: Restorative Justice in the Pacific Islands, edited by Sinclair Dinnen, 255-264. Canberra: Pandanus Books.

UNDP (United Nations Development Programme). 2014. Peace and Development Analysis: Findings and Emerging Priorities. Port Moresby: United Nations Development Programme Papua New Guinea Country Office.

Vella, Louise. 2014a. 'What Will You Do with Our Stories?' Truth and Reconciliation in the Solomon Islands'. International Journal of Conflict and Violence 8 (1): 91-103.

Vella, Louise. 2014b. 'Translating Transitional Justice: The Solomon Islands Truth and Reconciliation Commission'. SSGM Discussion Paper 2014/2. Canberra: ANU.

Wallis, Joanne. 2014. Constitution Making during State Building. New York: Cambridge University Press. doi.org/10.1017/CBO9781107587700.

Wallis, Joanne, Renée Jeffery and Lia Kent. 2016. 'Political Reconciliation in Timor Leste, Solomon Islands and Bougainville: The Dark Side of Hybridity'. Australian Journal of International Affairs 70 (2): 159-178. doi.org/10.1080/ 10357718.2015.1113231. 
This text is taken from Civil Society and Transitional Justice in Asia and the Pacific, edited by Lia Kent, Joanne Wallis and Claire Cronin, published 2019 by ANU Press, The Australian National University,

Canberra, Australia.

doi.org/10.22459/CSTJAP.2019.08 